\title{
COVID-19 Severe acute respiratory syndrome coronavirus 2 (SARS-CoV-2) infection in children and adolescents: a systematic review of critically unwell children and the association with underlying comorbidities
}

\author{
Nia Williams ${ }^{1} \cdot$ Trisha Radia $^{1} \cdot$ Katharine Harman $^{2} \cdot$ Pankaj Agrawal $^{1}$ - James Cook ${ }^{2} \cdot$ Atul Gupta $^{2,3}$ (D)
}

Received: 17 July 2020 / Revised: 26 August 2020 / Accepted: 31 August 2020 / Published online: 10 September 2020

(C) The Author(s) 2020

\begin{abstract}
Data show that children are less severely affected with SARS-Covid-19 than adults; however, there have been a small proportion of children who have been critically unwell. In this systematic review, we aimed to identify and describe which underlying comorbidities may be associated with severe SARS-CoV-2 disease and death. The study protocol was in keeping with Preferred Reporting Items for Systematic Reviews and Meta-analyses (PRISMA) guidelines. A total of 1726 articles were identified of which 28 studies fulfilled the inclusion criteria. The 28 studies included 5686 participants with confirmed SARS-CoV-2 infection ranging from mild to severe disease. We focused on the 108 patients who suffered from severe/critical illness requiring ventilation, which included 17 deaths. Of the 108 children who were ventilated, the medical history was available for 48 patients. Thirty-six of the 48 patients (75\%) had documented comorbidities of which 11/48 (23\%) had pre-existing cardiac disease. Of the 17 patients who died, the past medical history was reported in 12 cases. Of those, 8/12 (75\%) had comorbidities.

Conclusion: Whilst only a small number of children suffer from COVID-19 disease compared to adults, children with comorbidities, particularly pre-existing cardiac conditions, represent a large proportion of those that became critically unwell.
\end{abstract}

\section{What is Known:}

- Children are less severely affected by SARS-CoV-2 than adults.

- There are reports of children becoming critically unwell with SARS-CoV-2 and requiring intensive care.

What is New:

- The majority of children who required ventilation for SARS-CoV-2 infection had underlying comorbidities.

- The commonest category of comorbidity in these patients was underlying cardiac disease.

Keywords Paediatric · Adolescent · COVID-19 - Severe acute respiratory syndrome coronavirus 2 (SARS-CoV-2) · Critically unwell $\cdot$ Comorbidities

Communicated by Peter de Winter

Atul Gupta

atul.gupta@kcl.ac.uk

Nia Williams

nia.williams00@imperial.ac.uk

Trisha Radia

trisharadia@nhs.net

Katharine Harman

K.Harman1@nhs.net

Pankaj Agrawal

Pankaj.agrawal@nhs.net
James Cook

jwa.cook@nhs.net

1 Department of Paediatric Medicine, King's College Hospital, London, UK

2 Department of Paediatric Respiratory Medicine, King's College Hospital, London SE5 9RS, UK

3 Institute for Women's and Children's Health, King's College London, London, UK 


\section{Abbreviations \\ COVID-19 \\ PIMS-TA \\ Coronavirus disease 2019 \\ Paediatric multisystem \\ inflammatory syndrome \\ temporally associated with \\ COVID-19}

SARS-CoV-2 Severe acute respiratory

syndrome coronavirus 2

\section{Introduction}

A cluster of cases of pneumonia of unknown cause was reported in Wuhan, China in December 2019 leading to the identification of a novel severe acute respiratory syndrome coronavirus 2 (SARS-Co-V-2) [1]. The virus has spread rapidly, causing wide outbreaks of the associated disease coronavirus disease 2019 (COVID-19) throughout the globe [2].

In adults, the spectrum of disease is well described ranging in severity from asymptomatic carriage to respiratory failure and death [3]. Following the diagnosis of the first paediatric patient with SARS-CoV-2 in China on January 20, 2020, children across the world have been infected [4]. Data show that children are less severely affected than adults, representing approximately $5 \%$ of those infected and less than $1 \%$ of hospital admissions $[5,6]$. However; there have been a small proportion of children who have been critically unwell requiring intensive care with reported fatalities in children under the age of 18. A recent systemic review assessing the clinical features and management of children with SARSCoV-2 infection reported that children were most likely to have mild symptoms, predominantly respiratory with a minority reporting gastrointestinal symptoms. Only 1 patient was identified with severe disease requiring intensive care, and no data was available on the role of comorbidities in the severity of paediatric COVID-19 [7].

There is a dearth of studies describing an association between risk factors and comorbidities and severe SARS-CoV-2 disease in children. This is relevant; as we move to the recovery phase of the pandemic and shielding restrictions are being relaxed, it is vital to identify patients who are at high risk of severe disease to be able to advise appropriately. In this systematic review, we aimed to identify and describe which underlying comorbidities may be associated with severe SARSCoV-2 disease and death in children.

\section{Methods}

\section{Search strategy and data sources}

To identify studies reporting clinical features of children who were critically unwell, defined as requiring invasive mechanical ventilation, with laboratory confirmed SARSCoV-2 infection, we systematically searched the MEDLINE (PubMed) electronic database from December 1st 2019 to 31st May 2020 using key terms "covid 19 OR coronavirus OR sars-cov2 AND children OR adolescents OR neonate OR infant". We hand searched the reference lists from retrieved studies and reviews to find additional studies and contacted experts in the field. We also included some additional studies from June 2020 that were found through reading research bulletins so as to not miss key data in this rapidly developing research area.

\section{Study selection}

Two reviewers independently screened titles and abstracts of all citations for eligibility and retrieved those that met the inclusion criteria. If insufficient information was available in the abstract to decide on eligibility, the whole article was retrieved for review. Discrepancies were resolved by discussion and by involving a third reviewer when necessary.

We included case reports, case series, and other observational studies in children under the age of 18 . We excluded studies for which the full article was not available and studies that did not contain any original data such as review articles, commentaries and correspondence. Papers reporting information on both children and adults were included only if paediatric data could be retrieved. We excluded studies that focused on other serotypes of severe acute respiratory syndrome coronavirus and Middle East respiratory syndrome coronavirus infection. We excluded papers presenting cases of paediatric multisystem inflammatory syndrome temporally associated with COVID-19 (PIMS-TA).

The study protocol was in keeping with Preferred Reporting Items for Systematic Reviews and Meta-analyses (PRISMA) guidelines.

\section{Data extraction}

A structured data extraction form was piloted and then used to extract data for all included studies by two reviewers in duplicate. For all articles that we included, if available, we extracted the following data: first author, title, year of publication, country, study design, number of cases, gender, age of patients, comorbidities, clinical manifestations, laboratory tests, radiological findings, treatments and outcomes.

\section{Results}

A total of 1,726 articles were retrieved from the electronic search and another 4 were included from a research bulletin recommended by an expert in the field. One thousand five hundred ten articles were excluded after previewing the title 
and abstract. The remaining 220 papers were retrieved for full text review. A total of 28 papers met the inclusion criteria and were included for analysis (Fig. 1).

We found a total of 5,686 paediatric cases of SARS-CoV, of which a total of $108(1.9 \%)$ had severe SARS-CoV-2 requiring mechanical ventilation including $17(0.3 \%)$ deaths. Not all studies reported details of patient comorbidities. Of the 108 children who were mechanically ventilated, the medical history was available for 48 patients. Thirty-six of the 48 (75\%) had documented comorbidities and $12(25 \%)$ were previously fit and well. Of the 17 patients who died, the past medical history was available for 12 patients; 8 had comorbidities $(75 \%)$ and $4(25 \%)$ did not (Table 1). One of the children who died was not intubated due to pre-existing comorbidities.

\section{Comorbidities}

The details of documented comorbidities of those children who required mechanical ventilation with SARS-CoV-19 are summarised in Table 2.

\section{Age}

Many of the articles either did not report explicitly on the age of the patients with severe disease. For the patients who required mechanical ventilation or died for whom this data was available, 13 were $<1$ year of age and 25 were $>1$ year of age. Specifically, looking at the patients who died from SARS$\mathrm{CoV}-19$, age was documented in 13/17, of whom 2 were under the age of one (Table 3 ). The youngest patient to require mechanical ventilation was an ex preterm neonate in Italy and the youngest death reported was in a 5-month-old infant from Spain who had a history of muccopolysacharidosis type 1 and pre-existing cardiac failure.

\section{Discussion}

\section{Main findings}

This is the first systematic review of children who have suffered critical illness following SARS-CoV-2 infection and in

Fig. 1 Quorum diagram

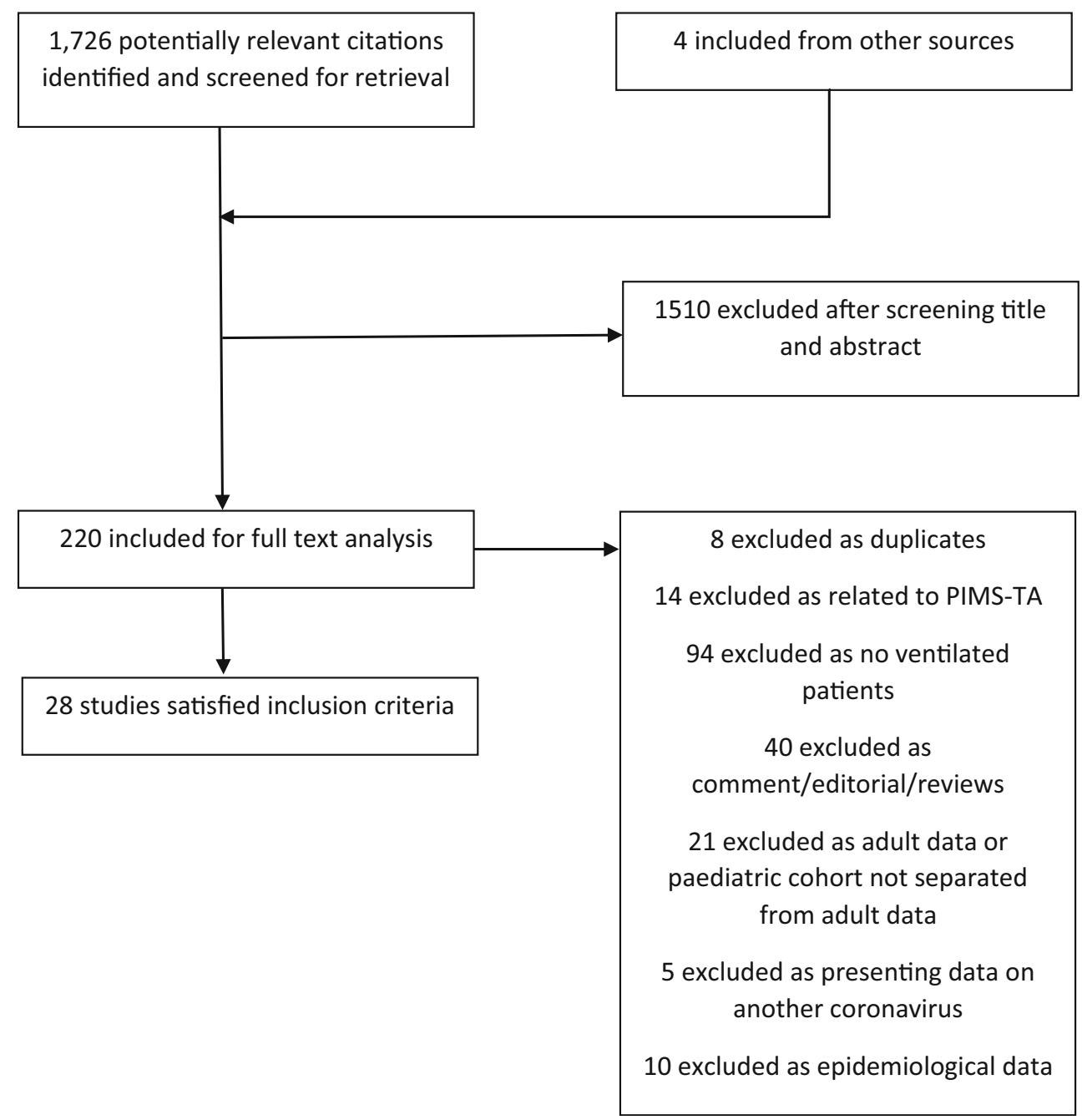




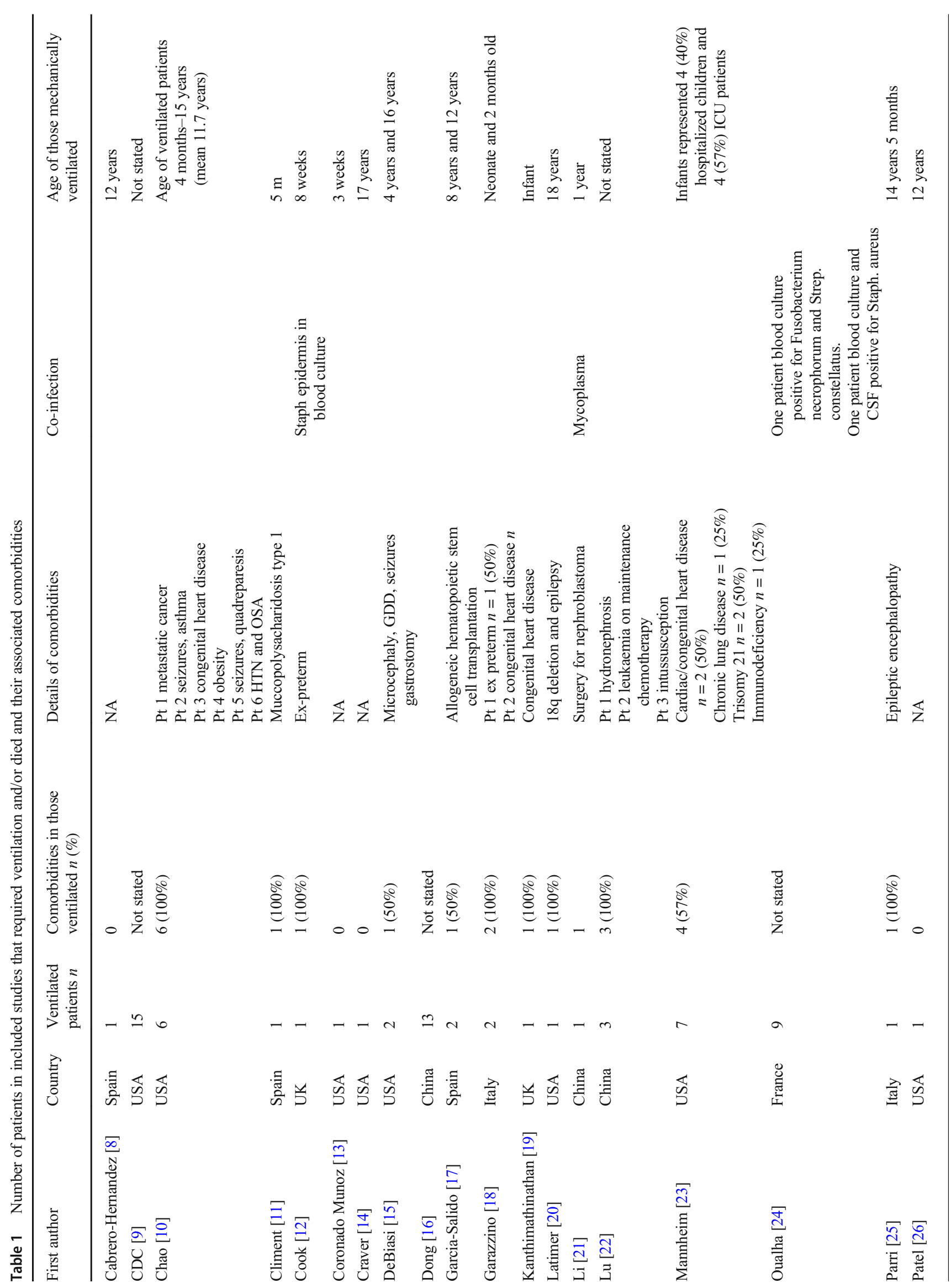




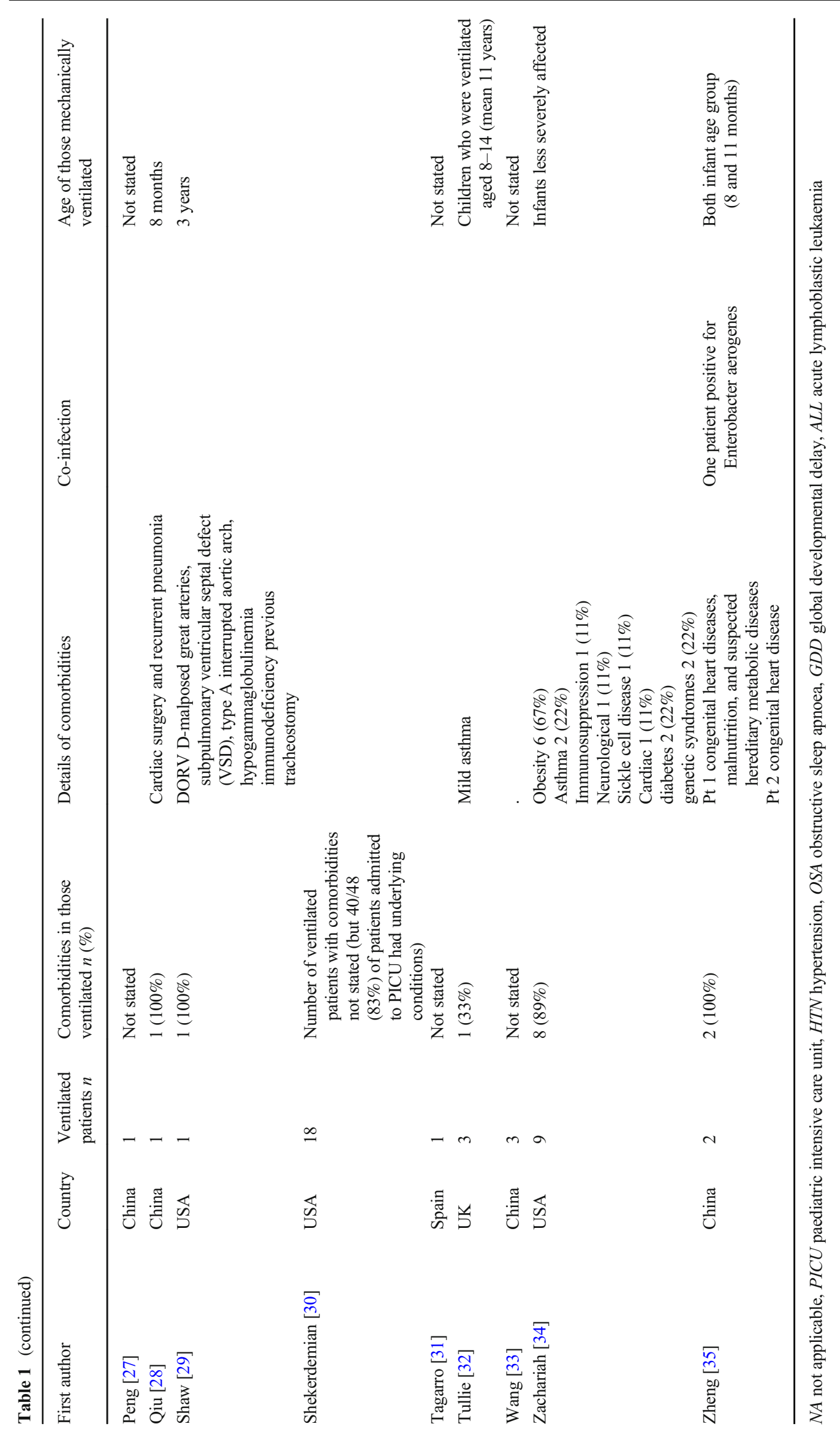


whom past medical history has been reported. In keeping with previous reports, the data presented show that the absolute risk of critical illness in children is low with intensive care treatment an infrequent occurrence. However, we have identified for the first time, that children with comorbidities have an increased relative risk of critical illness; this group comprising the majority of children who have required mechanical ventilation and the majority of children who have died. The comorbidities identified encompass a broad spectrum of diseases, cardiac disease being the most frequent. This is in keeping with a recent systematic review which looked specifically at cardiac disease in paediatric patients with SARS-CoV-19 and concluded that previous cardiac surgery is related with the risk of a more severe form of the disease [36].

\section{Interpretation}

There are two fascinating features of SARS-CoV-2 as pertaining to disease in children; the risk of acquiring the infection appears to be lower than in adults ( $1 \% \mathrm{v} 3.5 \%)$, and once infected, the risk of severe disease is almost 25 times lower than in adults [6].
The immune mechanisms underlying the duel phenomena of enhanced resistance to infection and enhanced resistance to severe disease are yet to be elucidated; however, the magnitude of this effect appears sufficient to protect most children with comorbidities from severe disease. Indeed, the data presented showed that only a small number of children with comorbidities actually suffered from critical illness, though data on pre-existing comorbidities was only available in 48 of the 108 patients who required mechanical ventilation.

Despite the low absolute risk of critical disease in children, the data presented show an increased relative risk for children with comorbidities. Chronic cardiac disease, respiratory disease and obesity are prominent comorbidities associated with critical disease. Interestingly, these comorbidities are also described as risk factors for severe disease in adults. In a large prospective observational cohort study of adults with severe COVID-19 infection, the most frequent comorbidities identified were chronic cardiac disease (29\%), diabetes (19\%), non-asthmatic chronic pulmonary disease (19\%), asthma (14\%) and obesity (11\%) [37].

In contrast to adult data, immunological, haematological and oncological disease (with presumed immunosuppression)
Table 2 Documented comorbidities in mechanically ventilated children with SARS-CoV-19 (some patients had more than one comorbidity)

\begin{tabular}{|c|c|}
\hline \multicolumn{2}{|l|}{ Cardiovascular } \\
\hline Cardiovascular including congenital heart disease and cardiomyopathy & $10 / 48(21 \%)$ \\
\hline Hypertension & $1 / 48(2 \%)$ \\
\hline Mucopolysacharidosis with cardiac failure & $1 / 48(2 \%)$ \\
\hline \multicolumn{2}{|l|}{ Neurological } \\
\hline Epilepsy, neurodegenerative disorders and cerebral palsy & $5 / 48(10 \%)$ \\
\hline \multicolumn{2}{|l|}{ Respiratory } \\
\hline Asthma or reactive airway disease & $5 / 48(10 \%)$ \\
\hline Recurrent chest infections & $1 / 48(2 \%)$ \\
\hline OSA & $1 / 48(2 \%)$ \\
\hline \multicolumn{2}{|l|}{ Immunosuppressed/Oncology/Haematology } \\
\hline Allogeneic hematopoietic stem cell transplantation & $1 / 48(2 \%)$ \\
\hline Leukaemia on maintenance chemotherapy & $1 / 48(2 \%)$ \\
\hline Immunodeficiency & $3 / 48(6 \%)$ \\
\hline Sickle cell disease & $1 / 48(2 \%)$ \\
\hline Metastatic cancer & $1 / 48(2 \%)$ \\
\hline Nephroblastoma & $1 / 48(2 \%)$ \\
\hline \multicolumn{2}{|l|}{ Genetic syndromes } \\
\hline Genetic syndrome unspecified & $2 / 48(4 \%)$ \\
\hline $\mathrm{T} 21$ & $2 / 48(4 \%)$ \\
\hline $18 \mathrm{q}$ deletion & $1 / 48(2 \%)$ \\
\hline \multicolumn{2}{|l|}{ Endocrine } \\
\hline Diabetes & $2 / 48(4 \%)$ \\
\hline Obesity & $7 / 48(15 \%)$ \\
\hline \multicolumn{2}{|l|}{ Other } \\
\hline Prematurity & $2 / 48(4 \%)$ \\
\hline Intussusception & $1(2 \%)$ \\
\hline Hydronephrosis & $1(2 \%)$ \\
\hline No comorbidity & $12(25 \%)$ \\
\hline
\end{tabular}


Table 3 Demographics of patients who died with SARS-CoV-19

\begin{tabular}{|c|c|c|c|c|c|c|}
\hline First author & Number who died & Age & Sex & Ethnicity & Comorbidities & Other details \\
\hline $\mathrm{CDC}$ & 3 & - & - & - & - & - \\
\hline Chao & 1 & $11 \mathrm{y}$ & M & Black & Metastatic cancer & $\begin{array}{l}\text { Family chose to withdraw care after } \\
\text { a period of invasive mechanical ventilation }\end{array}$ \\
\hline Climent & 1 & $5 \mathrm{~m}$ & M & - & $\begin{array}{l}\text { Mucopolysaccharidosis } \\
\text { with heart failure }\end{array}$ & Was on ACE inhibitor prior to admission \\
\hline Craver & 1 & $17 \mathrm{y}$ & M & African American & Nil & $\begin{array}{l}\text { Eosinophilic myocarditis on post } \\
\text { mortem examination }\end{array}$ \\
\hline Dong & 1 & $14 \mathrm{y}$ & M & - & - & - \\
\hline $\mathrm{Lu}$ & 1 & $10 \mathrm{~m}$ & - & - & Intussusception & \\
\hline \multirow[t]{5}{*}{ Oualha } & 5 & $16 \mathrm{y}$ & $\mathrm{F}$ & & Nil & \\
\hline & & $16 \mathrm{y}$ & M & - & Nil & $\begin{array}{l}\text { Sphenoidal sinusitis with cavernous sinus } \\
\text { thrombosis. Blood culture positive for } \\
\text { Fusobacterium necrophorum and Strep. } \\
\text { constellatus. Left middle cerebral artery } \\
\text { stroke. }\end{array}$ \\
\hline & & $6 y$ & $\mathrm{~F}$ & - & Nil & $\begin{array}{l}\text { Myocarditis and septic shock. Blood culture } \\
\text { and CSF-positive for Staph aureus. } \\
\text { Underwent ECMO and suffered massive } \\
\text { brain haemorrhage. }\end{array}$ \\
\hline & & $4 y$ & M & - & $\begin{array}{l}\text { Chemotherapy for acute } \\
\text { lymphoblastic leukaemia }\end{array}$ & ARDS and multiorgan failure \\
\hline & & $17 \mathrm{y}$ & $\mathrm{F}$ & - & $\begin{array}{l}\text { Epilepsy and major neonatal } \\
\text { encephalopathy }\end{array}$ & $\begin{array}{l}\text { Not intubated due to mutual decision } \\
\text { to withdraw care }\end{array}$ \\
\hline \multirow[t]{2}{*}{ Shekerdemian } & 2 & $12 \mathrm{y}$ & - & - & $\begin{array}{l}\text { Had comorbidities but } \\
\text { no details given }\end{array}$ & Multiorgan failure \\
\hline & & $17 \mathrm{y}$ & - & - & $\begin{array}{l}\text { Had comorbidities but } \\
\text { no details given }\end{array}$ & Multiorgan failure \\
\hline Wang & 1 & $8 \mathrm{y}$ & M & - & ALL in remission & \\
\hline Zachariah & 1 & - & - & - & - & - \\
\hline
\end{tabular}

$M$ male, $F$ female, $y$ year, $m$ month

comprises $17 \%$ of comorbidities in the children described. This is surprising as it is thought that immunosuppression may have a protective effect in adults through interference with the aberrant inflammatory response associated with severe disease in adults [38]. Furthermore, studies of paediatric cohorts on immunosuppression have reported no increase in risk of severe disease [38-40]. Discerning an influence of immunosuppression may be difficult due to a relatively small effect, the influence of the underlying disease itself and the differing influences of different types of immunosuppression. Indeed, only a small number of immunosuppressed children identified in this study had critical disease implying that the absolute risk of critical disease associated with immunosuppression is small.

Older age has been found to be an important risk factor for severe disease in adults [37]. In children being less than 1 year of age has been reported to be a risk factor for severe disease [16]. In this review, we found that $35 \%$ of all children mechanically ventilated were infants under 1 year of age which suggests under 1's are disproportionately affected by severe COVID-19. This is in keeping with a large European multicentre study that found $29 \%$ of patients under 18 year of age infected with COVID-19 were in the infant age group and $48 \%$ of those admitted to ICU were under 2 years of age [41].

In the UK and the USA, countries with ethnically diverse populations, mortality is disproportionately high in adult populations of ethnic minority groups, and those of lower socioeconomic status [42]. The complex factors underlying the relationship between COVID-19 and these demographic features are yet to be fully defined. We were unable to explore if these factors are important in severity of disease in children as socio-economic, and ethnicity data was rarely reported in the included studies.

The main weakness of this study was the potential missing data from studies that reported combined adult and paediatric data, where we were unable to extract the relevant paediatric data. Another weakness was that information on comorbidities was only available in 48 of the 108 patients who required mechanical ventilation, and more detail on the demographics and past medical history of all patients included would strengthen the conclusions and avoid selection bias. We are also aware that in this rapidly developing research area, new data is being published daily that may complement the data in this review. We must also stress that this data cannot be used 
to estimate individual risk as there is no universal testing; we cannot be sure how many children in a population are infected with COVID-19 at any one time. The majority of the included studies are from developed countries, and the impact on the developing world needs to be further studied. The key strength of this systematic review is that it is the largest study to date to look at the effect of comorbidities in children with severe COVID-19 and may be able to contribute to the discussion on social distancing and shielding in this population.

\section{Conclusion}

Children with comorbidities have a predisposition to critical illness following infection with COVID-19 although the absolute risk remains low. These data are important in the assessment of risk with regard to the planned relaxation of social distancing measures for these children and their families. Prospective data collection is required to better define risk factors for severe disease including comorbidities, age, ethnicity and socio-economic status.

Authors' contributions Data collection (screening papers/data extraction) NW, TR, PA

Interpretation: $\mathrm{NW}, \mathrm{TR}, \mathrm{PA}, \mathrm{JC}, \mathrm{KH}, \mathrm{AG}$

Original draft preparation: $\mathrm{NW}$

Review and editing: TR, PA, JC, KH, AG

All authors reviewed and approved the final version of the manuscript.

\section{Compliance with ethical standards}

Conflict of interest The authors declare that they have no conflict of interest.

Ethical approval This article does not contain any studies with human participants or animals performed by any of the authors.

Open Access This article is licensed under a Creative Commons Attribution 4.0 International License, which permits use, sharing, adaptation, distribution and reproduction in any medium or format, as long as you give appropriate credit to the original author(s) and the source, provide a link to the Creative Commons licence, and indicate if changes were made. The images or other third party material in this article are included in the article's Creative Commons licence, unless indicated otherwise in a credit line to the material. If material is not included in the article's Creative Commons licence and your intended use is not permitted by statutory regulation or exceeds the permitted use, you will need to obtain permission directly from the copyright holder. To view a copy of this licence, visit http://creativecommons.org/licenses/by/4.0/.

\section{References}

1. Guan WJ, Ni ZY, Hu Y, Liang WH, Ou CQ, He JX, Liu L, Shan H, Lei CL, Hui DSC, du B, Li LJ, Zeng G, Yuen KY, Chen RC, Tang CL, Wang T, Chen PY, Xiang J, Li SY, Wang JL, Liang ZJ, Peng YX, Wei L, Liu Y, Hu YH, Peng P, Wang JM, Liu JY, Chen Z, Li
G, Zheng ZJ, Qiu SQ, Luo J, Ye CJ, Zhu SY, Zhong NS, China Medical Treatment Expert Group for Covid-19 (2020) Clinical characteristics of coronavirus disease 2019 in China. N Engl J Med 382(18):1708-1720

2. World Health Organization (WHO). WHO Director-General's opening remarks at the media briefing on COVID-19: 11 March 2020. Published March 11, 2020. Accessed 30 ${ }^{\text {th }}$ June 2020

3. Rodriguez-Morales AJ, Cardona-Ospina JA, Gutiérrez-Ocampo E, Villamizar-Peña R, Holguin-Rivera Y, Escalera-Antezana JP, Alvarado-Arnez LE, Bonilla-Aldana DK, Franco-Paredes C, Henao-Martinez AF, Paniz-Mondolfi A, Lagos-Grisales GJ, Ramírez-Vallejo E, Suárez JA, Zambrano LI, Villamil-Gómez WE, Balbin-Ramon GJ, Rabaan AA, Harapan H, Dhama K, Nishiura H, Kataoka H, Ahmad T, Sah R, Latin American Network of Coronavirus Disease 2019-COVID-19 Research (LANCOVID-19). Electronic address: https://www.lancovid.org (2020) Clinical, laboratory and imaging features of COVID-19: a systematic review and meta-analysis. Travel Med Infect Dis 34: 101623

4. Chan JF, Yuan S, Kok KH et al (2020) A familial cluster of pneumonia associated with the 2019 novel coronavirus indicating person-to-person transmission: a study of a family cluster. Lancet. 395(10223):514-523

5. Wu C, Chen X, Cai Y et al (2020) Risk factors associated with acute respiratory distress syndrome and death in patients with coronavirus disease 2019 pneumonia in Wuhan, China [published online ahead of print, 2020 Mar 13]. JAMA Intern Med 180(7):1-11

6. Ludvigsson JF (2020) Systematic review of COVID-19 in children shows milder cases and a better prognosis than adults. Acta Paediatr 109(6):1088-1095

7. Castagnoli R, Votto M, Licari A, Brambilla I, Bruno R, Perlini S, Rovida F, Baldanti F, Marseglia GL (2020) Severe acute respiratory syndrome coronavirus 2 (SARS-CoV-2) infection in children and adolescents: a systematic review [published online ahead of print, 2020 Apr 22]. JAMA Pediatr. https://doi.org/10.1001/ jamapediatrics.2020.1467

8. Cabrero-Hernández M, García-Salido A, Leoz-Gordillo I, AlonsoCadenas JA, Gochi-Valdovinos A, González Brabin A, de Lama Caro-Patón G, Nieto-Moro M, de-Azagra-Garde AM, SerranoGonzález A (2020) Severe SARS-CoV-2 infection in children with suspected acute abdomen: a case series from a tertiary hospital in Spain [published online ahead of print, 2020 May 26]. Pediatr Infect Dis J 39:e195-e198. https://doi.org/10.1097/INF. 0000000000002777

9. CDC COVID-19 Response Team (2020) Coronavirus disease 2019 in children - United States, February 12-April 2, 2020. MMWR Morb Mortal Wkly Rep 69(14):422-426 Published 2020 Apr 10

10. Chao JY, Derespina KR, Herold BC et al (2020) Clinical characteristics and outcomes of hospitalized and critically ill children and adolescents with coronavirus disease 2019 (COVID-19) at a tertiary care medical center in New York City [published online ahead of print, 2020 May 11]. J Pediatr S0022-3476(20):30580-30581

11. Climent FJ, Calvo C, García-Guereta L, Rodríguez-Álvarez D, Buitrago NM, Pérez-Martínez A (2020) Fatal outcome of COVID-19 disease in a 5-month infant with comorbidities [published online ahead of print, 2020 Apr 27]. Rev Esp Cardiol (Engl Ed) S1885-5857(20):30172-30179

12. Cook J, Harman K, Zoica B, Verma A, D'Silva P, Gupta A (2020) Horizontal transmission of severe acute respiratory syndrome coronavirus 2 to a premature infant: multiple organ injury and association with markers of inflammation [published online ahead of print, 2020 May 19]. Lancet Child Adolesc Health S2352-4642(20): 30166-30168

13. Coronado Munoz A, Nawaratne U, McMann D, Ellsworth M, Meliones J, Boukas K (2020) Late-onset neonatal sepsis in a patient with Covid-19. N Engl J Med 382(19):e49 
14. Craver R, Huber S, Sandomirsky M, McKenna D, Schieffelin J, Finger L (2020) Fatal eosinophilic myocarditis in a healthy 17year-old male with severe acute respiratory syndrome coronavirus 2 (SARS-CoV-2c). Fetal Pediatr Pathol 39(3):263-268

15. DeBiasi RL, Song X, Delaney M et al (2020) Severe COVID-19 in children and young adults in the Washington, DC metropolitan region [published online ahead of print, 2020 May 13]. J Pediatr 223:199-203.e1. https://doi.org/10.1016/j.jpeds.2020.05.007

16. Dong Y, Mo X, Hu Y, Qi X, Jiang F, Jiang Z, Tong S (2020) Epidemiology of COVID-19 among children in China. Pediatrics. 145(6): 20200702

17. García-Salido A, Leoz-Gordillo I, Martínez de Azagra-Garde A et al (2020) Children in critical care due to severe acute respiratory syndrome coronavirus 2 infection: experience in a Spanish hospital [published online ahead of print, 2020 May 27]. Pediatr Crit Care Med. https://doi.org/10.1097/PCC.0000000000002475

18. Garazzino S, Montagnani $\mathrm{C}$, Donà D et al (2020) Multicentre Italian study of SARS-CoV-2 infection in children and adolescents, preliminary data as at 10 April 2020. Euro Surveill 25(18):2000600

19. Kanthimathinathan HK, Dhesi A, Hartshorn S et al (2020) COVID19: a UK children's hospital experience. Hosp Pediatr 10(9):802805

20. Latimer G, Corriveau C, DeBiasi RL et al (2020) Cardiac dysfunction and thrombocytopenia-associated multiple organ failure inflammation phenotype in a severe paediatric case of COVID-19 [published online ahead of print, 2020 May 18]. Lancet Child Adolesc Health S2352-4642(20):30163-30162

21. Li Y, Cao J, Zhang X, Liu G, Wu X, Wu B (2020) Chest CT imaging characteristics of COVID-19 pneumonia in preschool children: a retrospective study. BMC Pediatr 20(1):227 Published 2020 May 18

22. Lu X, Zhang L, Du H et al (2020) SARS-CoV-2 infection in children. N Engl J Med 382(17):1663-1665

23. Mannheim J, Gretsch S, Layden JE, Fricchione MJ (2020) Characteristics of hospitalized pediatric COVID-19 cases Chicago, Illinois, March - April 2020 [published online ahead of print, 2020 Jun 1]. J Pediatric Infect Dis Soc

24. Oualha M, Bendavid M, Berteloot L, Corsia A, Lesage F, Vedrenne M, Salvador E, Grimaud M, Chareyre J, de Marcellus C, Dupic L, de Saint Blanquat L, Heilbronner C, Drummond D, Castelle M, Berthaud R, Angoulvant F, Toubiana J, Pinhas Y, Frange P, Chéron G, Fourgeaud J, Moulin F, Renolleau S (2020) Severe and fatal forms of COVID-19 in children. Arch Pediatr 27(5):235-238

25. Parri N, Lenge M, Buonsenso D (2020) Coronavirus infection in pediatric emergency departments (CONFIDENCE) Research Group. Children with Covid-19 in pediatric emergency departments in Italy. N Engl J Med 383(2):187-190

26. Patel PA, Chandrakasan S, Mickells GE, Yildirim I, Kao CM, Bennett CM (2020) Severe pediatric COVID-19 presenting with respiratory failure and severe thrombocytopenia [published online ahead of print, 2020 May 4]. Pediatrics. 146:e20201437

27. Peng H, Gao P, Xu Q et al (2020) Coronavirus disease 2019 in children: characteristics, antimicrobial treatment, and outcomes [published online ahead of print, 2020 May 7]. J Clin Virol 128:104425

28. Qiu L, Jiao R, Zhang A, Chen X, Ning Q, Fang F, Zeng F, Tian N, Zhang Y, Huang Y, Sun Z, Dhuromsingh M, Li H, Li Y, Xu R, Chen Y, Luo X (2020) A typical case of critically ill infant of coronavirus disease 2019 with persistent reduction of T lymphocytes [published online ahead of print, 2020 May 1]. Pediatr Infect Dis J. https://doi.org/10.1097/INF.0000000000002720 Publish Ahead of Print

29. Shaw R, Tighe N, Odegard KC, Alexander P, Emani S, Yuki K (2020) Intubation precautions in a pediatric patient with severe COVID-19. J Pediatr Surg Case Rep 58:101495

30. Shekerdemian LS, Mahmood NR, Wolfe KK, Riggs BJ, Ross CE, McKiernan CA, Heidemann SM, Kleinman LC, Sen AI, Hall MW,
Priestley MA, McGuire JK, Boukas K, Sharron MP, Burns JP, for the International COVID-19 PICU Collaborative (2020) Characteristics and outcomes of children with coronavirus disease 2019 (COVID-19) infection admitted to US and Canadian pediatric intensive care units [published online ahead of print, 2020 May 11]. JAMA Pediatr. https://doi.org/10.1001/jamapediatrics.2020.1948

31. Tagarro A, Epalza C, Santos M et al (2020) Screening and severity of coronavirus disease 2019 (COVID-19) in Children in Madrid, Spain [published online ahead of print, 2020 Apr 8]. JAMA Pediatr:e201346

32. Tullie L, Ford K, Bisharat M et al (2020) Gastrointestinal features in children with COVID-19: an observation of varied presentation in eight children [published online ahead of print, 2020 May 19]. Lancet Child Adolesc Health S2352-4642(20):30165-30166

33. Wang Y, Zhu F, Wang C (2020) The risk of Children Hospitalized With Severe COVID-19 in Wuhan [published online ahead of print, 2020 May 6]. Pediatr Infect Dis J. https://doi.org/10.1097/INF 0000000000002739

34. Zachariah P, Johnson CL, Halabi KC, Ahn D, Sen AI, Fischer A, Banker SL, Giordano M, Manice CS, Diamond R, Sewell TB, Schweickert AJ, Babineau JR, Carter RC, Fenster DB, Orange JS, McCann TA, Kernie SG, Saiman L, for the Columbia Pediatric COVID-19 Management Group (2020) Epidemiology, clinical features, and disease severity in patients with coronavirus disease 2019 (COVID-19) in a children's hospital in New York City, New York [published online ahead of print, 2020 Jun 3]. JAMA Pediatr:e202430

35. Zheng F, Liao C, Fan QH et al (2020) Clinical characteristics of children with coronavirus disease 2019 in Hubei, China. Curr Med Sci 40(2):275-280

36. Sanna G, Serrau G, Bassareo PP, Neroni P, Fanos V, Marcialis MA (2020) Children's heart and COVID-19: up to date evidence in the form of a systematic review. Eur Journal Paed 179:1079-1087

37. Docherty AB, Harrison EM, Green CA et al (2020) Features of 20 133 UK patients in hospital with covid-19 using the ISARIC WHO clinical characterisation protocol: prospective observational cohort study. BMJ 369:m1985 Published 2020 May 22

38. Warraich R, Amani L, Mediwake R, Tahir H (2020) Immunosuppression drug advice and COVID-19: are we doing more harm than good. Br J Hosp Med (Lond) 81(6):1-3

39. Marlais M, Wlodkowski T, Vivarelli M, Pape L, Tönshoff B, Schaefer F, Tullus K (2020) The severity of COVID-19 in children on immunosuppressive medication [published online ahead of print, 2020 May 13]. Lancet Child Adolesc Health 4(7):e17-e18

40. Turner D, Huang Y, Martín-de-Carpi J, Aloi M, Focht G, Kang B, Zhou Y, Sanchez C, Kappelman MD, Uhlig HH, Pujol-Muncunill G, Ledder O, Lionetti P, Dias JA, Ruemmele FM, Russell RK (2020) Corona virus disease 2019 and paediatric inflammatory Bowel diseases: global experience and provisional guidance (March 2020) from the Paediatric IBD Porto Group of European Society of Paediatric Gastroenterology, Hepatology, and Nutrition. J Pediatr Gastroenterol Nutr 70(6):727-733

41. Gotzinger et al (2020) COVID-19 in children and adolescents in Europe: a multinational, multicentre cohort study. Lancet Child Adolescent Health 4:653-661. https://doi.org/10.1016/s23524642(20)30177-2

42. Office for National Statistics. Coronavirus COVID-19 related deaths by ethnic group, England and Wales: 2 March 2020 to 10 April 2020. Accessed June 30th 2020 (https://www.ons.gov.uk/ peoplepopulationandcommunity/birthsdeathsandmarriages/deaths/ articles/coronavirusrelateddeathsbyethnicgroupenglandandwales/ 2march2020to10april2020

Publisher's note Springer Nature remains neutral with regard to jurisdictional claims in published maps and institutional affiliations. 